\title{
THE INCOME TAX PROGRESSION DEPENDING ON SOCIAL INSURANCE CONTRIBUTIONS IN POLAND
}

\author{
EDYTA MAZUREK \\ Wrocław University of Economics, Faculty of Management, Computer Science and Finance, \\ Department of Statistics, Komandorska Street 118/120, 53-345 Wrocław, Poland \\ email: edyta.mazurek@ue.wroc.pl
}

\begin{abstract}
The tax system is described by a set of parameters such as: tax brackets, a statutory tax rate, and tax-free income. Social and health insurance contributions supplement the tax system. The Polish social insurance system includes: old-age pension insurance, disability pension insurance, sickness insurance and work accident insurance. They don't formally constitute the tax system, but indeed through its character as compulsory contributions (dependent on the level of income) one should treat them this way. The parameters mentioned earlier, shape the tax system and influence its characteristics such as: a degree of progression, a redistributive effect on the distribution of income and tax revenues. The main aim of the presented paper is the assessment of the influence of the contributions of the Polish social insurance system on the degree of progression.
\end{abstract}

Key words: personal income tax, statutory tax rate, tax-free income, social insurance system and the progressivity index.

DOI: $10.15611 /$ amse.2014.17.21

\section{Introduction}

Personal income tax, as it directly affects all of us taxpayers, is the tax that arouses the strongest emotions in political debates. One of the basic issues discussed in the literature is the selection of an appropriate tax rates and tax brackets. These conditions determine the nature of the tax, which is how they decide on whether it is progressive or linear.

In the majority of the European Union states, including Poland, the progressive tax has been adopted not only with different tax scales, but also with varying tax allowances and exemptions. Both the extent of tax progressiveness and all other kinds of allowances and exemptions affect the income redistribution and the fairness of the tax system (Kośny and Mazurek, 2009, Mazurek, 2013).

The tax system is described by a set of parameters such as: a tax brackets, a statutory tax rate, and tax-free income. Social insurance contributions supplement the tax system. The Polish social insurance system includes: old-age pension insurance, disability pension insurance, sickness insurance, work accident insurance and health insurance. They don't formally constitute the tax system, but indeed through its character as compulsory contributions (dependent on the level of income) one should treat them this way. The parameters mentioned earlier shape the tax system and influence its characteristics such as: a progression index, a redistributive effect and tax revenues. In the literature on the subject, authors compare progressivity of the tax and exclusion of social insurance contributions (Wagstaff et al., 1999) or study how the degree of progressivity of the income tax has changed during the time (Mathews, 2014). 


\section{$17 \backsim$ APPLICATIONS OF

In this paper we focus on analyzing how the social insurance contributions have influence on the degree of progression of the income tax system. It allows us to focus on how tax schedules influence progression and the consequent on the redistributive effect. Mazurek (manuscript) assesses the influence in more details of other aforementioned parameters on statistical characteristics of the tax system. The analysis is conducted based on the income data from tax offices and simulated tax systems. The knowledge of such dependence will make it possible to control, through progression and the redistribution of income, which is one of the basic tax functions, while maintaining the fairness of the tax system.

\section{Polish personal income tax}

In Poland, PIT was introduced in 1992 by the Act on Personal Income Tax (Ustawa z dnia 26 lipca 1991). Under the Act in force, the due tax depends on a set of parameters:

- deductible expenses,

- tax free income,

- tax brackets and tax rate,

- contributions to old-age pension, disability pension, sickness and health and work accident insurance.

In addition, the Polish PIT system includes numerous allowances and deductions applicable to both income and tax, e.g. rehabilitation allowance, Internet allowance or a child tax credit. However, as the above allowances concern only a selected group of taxpayers, they have not been taken into consideration in the examination.

Deductible expenses $(d e)$ are the expenses incurred by a taxpayer to earn revenue from a respective source. The provisions of the Acts on taxes (Act on Personal Income Tax and Act on Corporate Income Tax) do not specify which expenses can be recognised as the deductible ones. They provide, however, a catalogue of expenses that may not be recognised as such. Deductible expenses are not only incurred by the taxpayers running a business activity, but also by the taxpayers hired on the basis of, for example, a contract of employment. In the latter case deductible expenses are defined as a specific amount. In the years 2008-2014 deductible expenses of a taxpayer earning his or her income in one workplace were at the level of PLN 111.25 per month, i.e. PLN 1335 on an annual basis. Deductible expenses reduce revenue, thus establishing the tax base.

Although the concept of a tax-free income (tfe) has not been provided for in the Act on tax, every year a fixed amount, specified in the Act, can be deducted from the calculated tax, thus decreasing the computed tax to be paid. Since 2009, the fixed amount of PLN 556.02, decreasing the tax, has been in effect, which, taking into account the lowest tax rate of $18 \%$ effective in these years, determines the personal tax allowance at the level of PLN 3089 $\left(\frac{556.02}{18} \cdot 100=3089\right)$

. It means that the taxpayers whose income in a tax year is lower than PLN 3089 do not pay any income tax.

Income brackets and the tax rate, defining the nature of the tax, represent one of the major income tax parameters raised in political debates. In Poland the progressive tax system is in effect. Although the linear (proportionate) tax or the flat-rate tax have been broadly discussed in Poland, they have never been implemented as the personal income tax. It should be noted that the linear tax is often confused with the flat-rate tax. Both these taxes have one tax rate 


\section{APPLICATIONS OF \\ $\sum$ Mathematics And Statistics \\ th $<$ IN ECONOMICS}

International Scientific Conference | Poland • 27-31 August 2014

for all incomes, and the difference consists of the absence of a tax-free income in the linear tax. Initially, three tax thresholds (income brackets) were effective in Poland, with different tax rates, however, since 2009, two thresholds have been in force, with a tax rate of $18 \%$ and $32 \%$, respectively. At present, the majority of taxpayers submit their tax returns prepared according to the first tax scale (see Table 1). Although the share of taxpayers submitting their returns prepared according to the first tax scale has been decreasing since 2009, it still remains considerably high: from $98.41 \%$ in 2009 to $97.69 \%$ in 2012 . In $2010,98.11 \%$ of the taxpayers whose income was in the first income bracket, provided $77.32 \%$ of the personal income tax due. In the subsequent years, both the share of the taxpayers filing their returns drawn up according to the first tax scale and the share of the personal income tax due were decreasing.

Table 1. Structure of taxpayers and tax burden in 2009-2012.

\begin{tabular}{|c|l|l|c|c|}
\hline Year & $\begin{array}{c}\text { Taxable income } \\
{[\text { PLN] }}\end{array}$ & $\begin{array}{c}\text { Tax rate } \\
{[\%]}\end{array}$ & $\begin{array}{c}\text { Percentage } \\
\text { of taxpayers } \\
{[\%]}\end{array}$ & $\begin{array}{c}\text { Percentage } \\
\text { of due PIT } \\
{[\%]}\end{array}$ \\
\hline 2009 & up to 85 528 & 18 & 98.41 & 76.97 \\
& 85529 and over & 32 & 1.59 & 23.03 \\
\hline 2010 & up to 85 528 & 18 & 98.11 & 77.32 \\
& 85 529 and over & 32 & 1.89 & 22.68 \\
\hline 2011 & up to 85 528 & 18 & 97.89 & 76.28 \\
& 85 529 and over & 32 & 2.11 & 23.72 \\
\hline 2012 & up to 85 528 & 18 & 97.69 & 73.44 \\
& 85 529 and over & 32 & 2.31 & 26.56 \\
\hline
\end{tabular}

Source: Information on the settlement of personal income tax for the years 2009-2012, Ministry of Finance, Income Tax Department.

Pursuant to the Act on the Social Security System of 13 October 1998 (Dz. U. /Journal of Laws/ of 2009, No. 205, item 1585 as amended) the pension, disability pension, health and accident insurance are mandatory in Poland. Formally, the component parts of the above insurance are not comprised in the tax system, but because of their real nature, as mandatory contributions depend on the level of income, they should be treated as such. Pursuant to Art. 15 and 22 of the Act on the Social Security System, the percentage rates applicable to the pension, disability pension and health insurance are identical for all the insured. The accident insurance contribution is the exception, as since 1 January 2003 it has been variable, being determined depending on the level of occupational risks and their consequences. The rules for establishing the percentage rates applicable to the accident insurance were set down in the Act of 30 October 2002 on Industrial Accidents and Occupational Diseases Insurance (Dz. U. of 2009, No. 167, item 1322) and in the Regulation of the Minister of Labour and Social Policy of 29 November 2002 on the variability of the percentage rate applicable to the contribution under the industrial accidents insurance. Table 2 presents the percentage rates applicable to social insurance contributions effective since 2012. 


\section{APPLICATIONS OF \\ MATHEMATICS AND Statistics \\ IN ECONOMICS}

International Scientific Conference | Poland • 27-31 August 2014

Table 2. Mandatory contribution on both the employer's and employee's side, in force in 2012.

\begin{tabular}{|r|c|c|c|}
\hline \multicolumn{1}{|r|}{ Contribution type } & $\begin{array}{c}\text { Percentage rates } \\
{[\%]}\end{array}$ & $\begin{array}{c}\text { Payable by employee } \\
{[\%]}\end{array}$ & $\begin{array}{c}\text { Payable by employer } \\
{[\%]}\end{array}$ \\
\cline { 1 - 3 } Insurance: & 19.52 & 9.76 & 9.76 \\
\hline disability pension & 8.00 & 1.50 & 6.50 \\
\hline sickness & 2.45 & 2.45 & - \\
\hline work accident & $0.67-3.86$ & - & $0.67-3.86$ \\
\hline health & 9.00 & 9.00 & - \\
\hline
\end{tabular}

Source: Act of 13 October 1998 on the Social Security System.

Contribution to the sickness and health insurance is fully financed by taxpayer from his or her own resources.

\section{Measurement of the degree of progression}

Progression in the income tax schedule implies departure from proportionality in the distribution of the tax burden. It exerts a redistributive effect on the distribution of income and provides potential for gains from splitting for certain types of income units. Thus, we need to be able to measure income tax progression along the income scale and be able to say which of the two alternative income tax systems is the more progressive.

It is important for the assessment of the impact of tax code changes to have a methodology for evaluating progression at different points in the income parade. Literature provides a lot of measures for the degree of tax progressivity. These measures can be divided into two groups: distributional and structural indexes (Kiefer, 2005). The value of distributional indexes depends upon both the tax structure and the income distribution. The measures are defined as a function of the pre-tax and post-tax values of the Gini index (Musgrave and Thin, 1948, Reynolds and Smolensky, 1977) or as the relation between an income concentration curve and a tax concentration curve (Kakwani, 1977 and 1979, Stroup, 2005, Mathews, 2014). The second group (structural indexes) depends on tax structure, but not on the income distribution.

Due to the fact that the aim of the article is the assessment of the impact of tax policy on the degree of tax progression, the structural indexes will be used. It will allow analyzing the degree of progression for each income level and comparing different tax systems for the same income distribution.

The most important and frequently used measures of income tax progression focus on the tax schedule and are based on the marginal and average rates of tax.

For convenience let us define the above terms by a mathematical formula.

Let: $x$ denotes pre-tax income, $\mu_{x}$ - mean pre-tax income,

$T(x)$ - the income tax schedule,

$a(x)=\frac{T(x)}{x}-$ the average rate of tax with $t(0)=0$,

$m(x)=T^{\prime}(x)$ - the marginal rate of tax, 


$$
\begin{aligned}
& \mu_{T} \text { - mean taxation, } \\
& y(x)=x-T(x) \text { - net income, } \mu_{Y} \text { - mean net income. }
\end{aligned}
$$

The first measure of income tax progression- the liability progression - is defined as the elasticity of tax liability to pre-tax income:

$$
L P(x)=\frac{m(x)}{a(x)}=\frac{T^{\prime}(x)}{T(x)} x .
$$

The second residual progression is defined as the elasticity of post-tax income to pre-tax income:

$$
R P(x)=\frac{1-m(x)}{1-a(x)}=\frac{(x-T(x))^{\prime}}{x-T(x)} x .
$$

According to the liability progression, income tax is progressive at $x_{0}$ if $L P\left(x_{0}\right)>1$; according to the residual progression, income tax is progressive at $x_{0}$ if $0<R P\left(x_{0}\right)<1$.

The measure of income tax progression has a simple economic meaning. $L P\left(x_{0}\right)>1$ means that the tax on extra monetary unit for a taxpayer with income $x_{0}$ exceeds his/her average tax burden for income $x_{0} .0<R P\left(x_{0}\right)<1$ means that an extra monetary unit leaves a taxpayer with gross income $x_{0}$ less net income. Both measures are equivalent to the general definition of tax progression, that average tax rate at income $x_{0}$ is an increasing function of income.

If the tax change involves an upward shift of the entire function $L P(x)$, then the tax has become more liability progressive everywhere. A reduction in $R P(x)$ means an increase in residual progression. Of course the property of income tax of being more progressive may depend on the income distribution to which it applies. In this situation, in order to examine the progression, one should use the global measures of tax progression (distributional indexes).

\section{The income tax progression for the Polish tax system}

The measures described above will be used to analyze the degree of progression of the Polis tax system. How it was described in the second paragraph, in Poland social insurance is mandatory. The paid tax depends on social insurance contributions. Some of these contributions reduce the taxable income, and the part reduces the calculated tax. For this reason, these contributions can have an importance in meaning for the income tax progression. At the beginning we will explain how social insurance contributions affect the income tax.

Let $x$ denotes pre-tax (brutto) income. It is the basis of assessment for social insurance contributions, having the data included in table 2 makes it possible to calculate the amount of appropriate contributions:

$$
\begin{array}{ll}
\text { old-age pension }(o) & o=9.76 \% \cdot x, \\
\text { disability pension }(\underline{d}) & d=1.5 \% \cdot x, \\
\text { sickness }(s) & s=2.45 \% \cdot x .
\end{array}
$$

These three contributions of social insurance are $13.71 \% \cdot x$. 


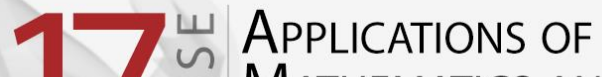

Annual basis of assessment of contributions to the old-age and disability pension insurance may not be higher than the 30-times amount of the forecast average monthly salary in the national economy for the given calendar year. It means that after the taxpayer exceeds a fixed amount of the gross income they stop paying contributions to the old-age and disability pension insurance. In the year 2013, the maximum annual amount basis of assessment of the contributions is PLN 111390.

A gross income reduced by social insurance contributions is a ground for calculating the contribution to health insurance, therefore the health contribution $(h)$ for the Polish income tax system is:

$$
h=9 \% \cdot(x-o-d-s)=9 \% \cdot(x-13.71 \% \cdot x) .
$$

A gross income reduced by social insurance contributions is also taxable income and according to the Polish tax rate schedule for the 2013 tax year (see paragraph 2) the tax is:

$$
\operatorname{tax}=18 \% \cdot(x-13.71 \cdot x-d e)-t f a+32 \% \cdot(x-13.71 \cdot x-d e-85528),
$$

where $d e$ is the deductible expense amount, and tfa - the tax-free amount.

The deductible expense amount in the 2013 tax year is PLN 1335 and the tax-free amount is PLN 556.02 (see paragraph 2) so:

$$
\operatorname{tax}=18 \% \cdot(0.8629 \cdot x-1335)-556.02+32 \% \cdot(0.8629 \cdot x-1335-85528) .
$$

$7.75 \%$ of the health contribution is tax-deductible in Poland and finally the net income (y) is:

$$
y=x-13.71 \% \cdot x-h-(\operatorname{tax}-7.75 \% \cdot(x-13.71 \cdot x)) .
$$

The Polish tax system makes the possibility of considering the tax in many different ways. In this paper we make an assessment of the degree of the tax income progression for two cases. In one of them the tax is considered with social and health insurance contributions (as $y-x)$ and the second case is when the tax is calculated without the social contributions according to the personal income tax rate:

$$
18 \% \cdot(x-1335)-556.02+32 \% \cdot(x-1335-85528) \text {. }
$$




\section{$1 \backsim$ APPLICATIONS OF \\ Mathematics and Statistics \\ IN ECONOMICS}

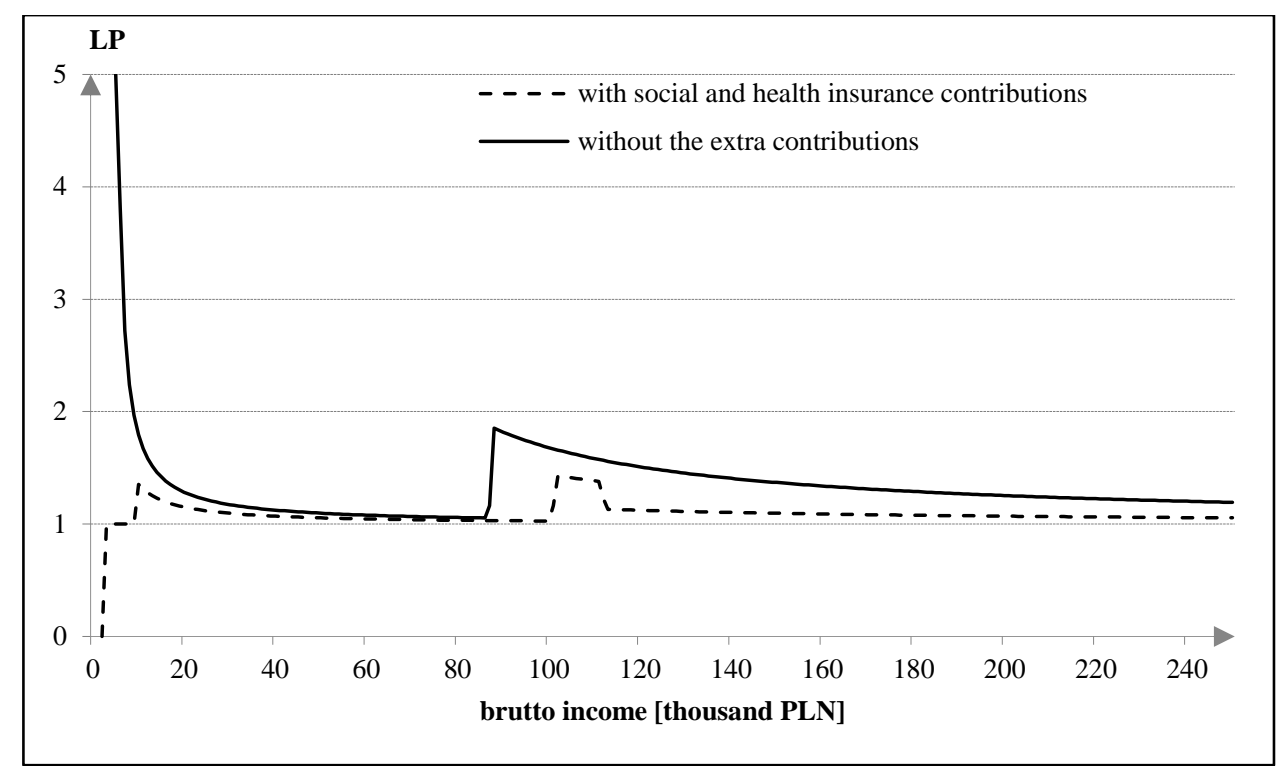

Figure 1 . The liability progression index for the Polish tax system Source: Own calculations and presentation.

Figure 1 presents the measure of the liability progression for two considered causes. The tax without the extra contributions involves an upward shift of the entire function $\operatorname{LP}(x)$, and then the tax has become more liability progressive everywhere. Generally we observe the high degree of progression at low income level. The degree of progression is decreasing with increased pre-tax income to the end of the first tax bracket. The next degree of progression jumps, and then decreases again. More irregular is the $L P(x)$ function for the tax with social insurance contributions due to the limitation of the basis for assessment of contributions to social insurance. The results presented in figure 2 are no longer so easy to interpret.

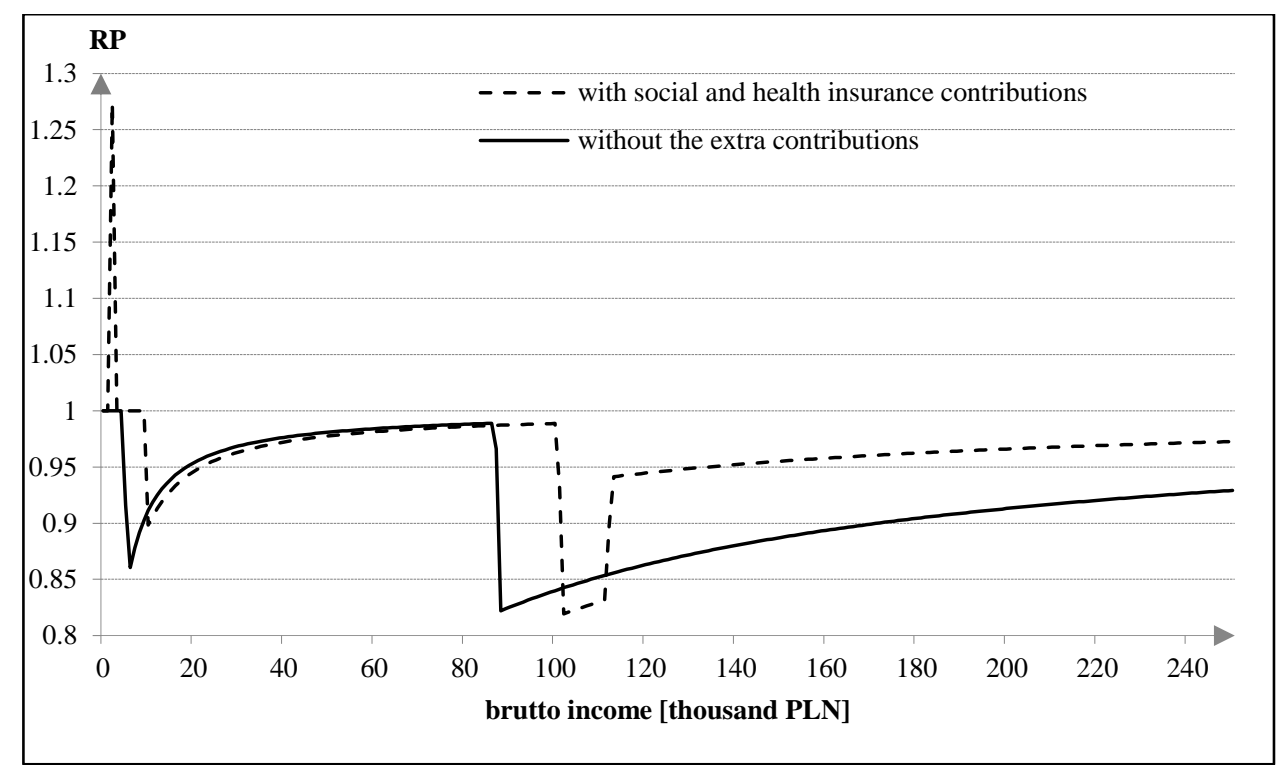

Figure 2. The residual progression index for the Polish tax system Source: Own calculations and presentation. 


\section{APPLICATIONS OF

The tax without extra contributions is not more of a progression, according to the $R P(x)$ measure. For this measure the number of tax brackets and a limit on the basis for assessment of contributions to social insurance have the meaning. For the pre-tax income from the first tax bracket the degree of RP progression of tax with social and health insurance contributions and of tax without the contributions are almost the same. The degree of tax with social insurance contributions progression at pre-tax income level greater than PLN 85528 is less than the degree of the tax without the social insurance contributions progression (a reduction in $R P(x)$ measure is interpreted as an increase in progression, according to this measure). Besides, there is a certain income level for which the tax with social insurance contributions progression is the highest. The income levels depend on a maximum basis for assessment of contributions to social insurance and on tax brackets. According to data included in table 1 approximately $98 \%$ of the taxpayers are getting the revenue in the first income bracket, therefore in fact the Polish tax system is characterized by a low degree of progression.

The proportional income tax is often discussed in Poland. The tax system with one tax rate and tax-free income is offered. The next step of the analysis will examine the progression of the tax system with one tax rate $-18 \%$. Other parameters of the tax system have been taken from the current tax system described in paragraph 2 .

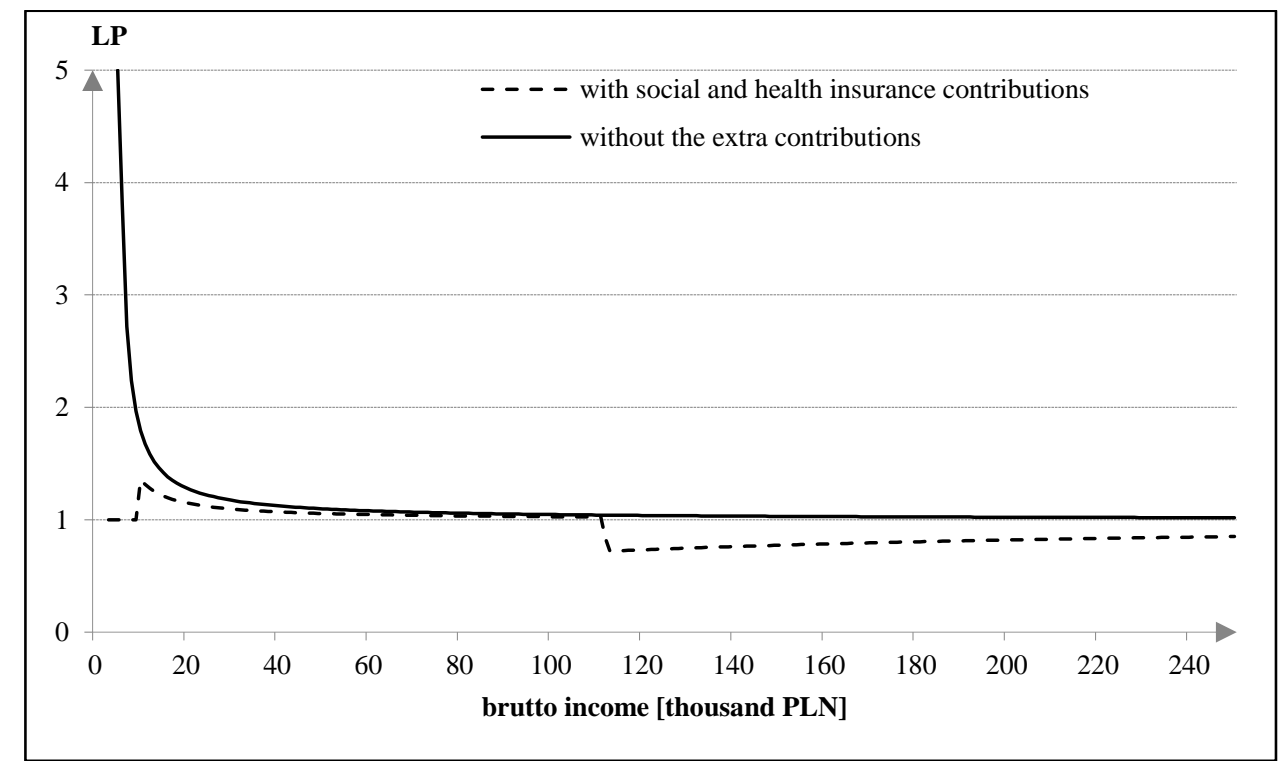

Figure 3. The liability progression index for the proportional tax system (18\%)

Source: Own calculations and presentation.

Figure 3 presents the measure of the liability progression for the proportional tax. The degree of tax with social and health insurance contribution progression at income levels greater than PLN 111390 (the maximum annual amount basis of assessment of the contributions to the old-age and disability pension insurance) is less than one. This means regressive system at the income level. If we consider the tax without additional contributions, the system is progressive everywhere, according to the $L P(x)$ measure. It shows how important the assessment degree of progression is in many of different ways. Similarly, the results showing the regressive tax system at some range of income level were received for two 
tax rates: $18 \%$ and $20 \%$, or $18 \%$ and $27 \%$. This means that the selection of the appropriate tax rate schedules is very important.

\section{Conclusion}

The social and health insurance contributions supplement the Polish tax system. The contributions are obligatory so they can be treated as an amount reducing income brutto. The contributions should be included in the measurement of real tax progression. If discussions over the equity of tax policy are couched in terms of income tax progression the aforementioned contributions should be taken into account, because this approach to the tax system has an impact on its progressivity. On the example of the Polish tax system the paper shows how big it might make a difference in the degree of progression using local measures of tax progression.

Analysis carried out shows how important it is to determine the assumptions in the analysis of the degree of progression. Different initial conditions may lead to extremely different conclusions: from the progressive to a regressive tax system. The selection of the appropriate tax rate schedules has a significant impact on the degree of tax progression and this process should be supported by the statistical analysis. Regardless, the basic concept of the tax progression index should prove useful for yielding meaningful insights into ongoing analysis and discussion over tax policy fairness.

\section{Acknowledgements}

The author is especially appreciative of the helpful suggestions provided by an anonymous referee. Any errors are solely those of the author.

\section{References}

1. KIEFER, D. W. 2005. Measures of Progressivity. In R. E. Cordes , J. J. Joseph, J. Gravelle (eds.), Encyclopedia of Taxation and Tax Policy. Washington D.C, Urban Institute Press. 2005.

2. KAKWANI, N. C. 1977. Measurement of Tax Progressivity: A Reply. The Economic Journal, 1979, vol. 89, no. 355, pp. 653-657.

3. KAKWANI, N. C. 1979. Measurement of Tax Progressivity: An International Comparison. The Economic Journal, 1977, vol. 87, no. 345, pp. 71-88.

4. KOŚNY, M., MAZUREK, E. 2009. Redistribution and Equity of Polish Personal Income Tax: Measurement Using Micro Data from Tax Returns. Statistica \& Applicazioni, 2009, vol. VII, no. 2, pp. 211-221.

5. MATHEWS, T. 2014. Historical trends in the degree of federal income tax progressivity in the Unitefd States. The Social Science Journal, 2014, 51, pp. 90-99.

6. MAZUREK, E. 2013. Statystyczna analiza podatku dochodowego od osób fizycznych. Prace Naukowe Uniwersytetu Ekonomicznego we Wrocławiu, 2013, n. 309, pp. 127-158.

7. MAZUREK, E. Manuscript. Characteristics of the Tax Systems Depending on the Parameters. Manuscript.

8. MUSGRAVE, R. A., THIN, T. 1948. Income tax progression, 1929-48. Journal of political Economy, 1948, 56 (6), pp. 498-514. 
9. REYNOLDS, M., SMOLENSKY, E. 1977. Public Expenditure, Taxes and the Distribution of Income: The United States, 1950, 1961, 1970. New York: Academic Press, 1977.

10. STROUP, M. D. 2005. An index for measuring tax progressivity. Economics Letters, 2005, 86 (2005), pp. 205-213.

11. Ustawa z dnia 26 lipca 1991 r. o podatku dochodowym od osób fizycznych. (DzU Nr 80, poz. $350 \mathrm{z}$ późn. zm.).

12. WAGSTAFF A. et al. 1999. Redistributive effect, progressivity and differential tax treatment: Personal income taxes in twelve OECD counties, Journal of Public Economics, 1999, 72, pp. 73-98. 